torhome during summer and winter vacation to the Hoover, Roosevelt, Truman, Eisenhower, and Kennedy libraries and used the Nixon papers in DC. This project grew from his 1983 Political Science Quarterly article on "Eisenhower as Party Leader." The subject is the relationship of presidents from FDR to LBJ to their national party committees. He leaves me with his manuscript!

Neil also leaves his two daughters, five sons (he was predeceased by one son), fourteen grandchildren, and three great-grandsons. To his colleagues and his family he was a strong, even a formidable, presence. His communications in public and private were never simple and explicit but always complex and involuted. He preferred not to direct students and children, but to provide the resources for them to find their own way. However, he did like to manage events and worked behind the scenes with energy and persistence to achieve the goals of the institutions he served. He recognized racial injustice early in his career, but came to feminism somewhat later. He had always noted exceptional ability in his female students, and by the late 1970s he also recognized that equitable opportunity for women required relief from their double burden and time and resources for their own work.

Neil had tremendous dignity, integrity, and self-determination. He did not ask for help or expect recognition and was surprised to receive an honor. When he needed external support for a project, he made sure that thorough preparation would ensure success, since he did not allow room for failure. He never acted on the basis of ideology; his own mind was always open to the consideration of new ideas. He even had a quirky sense of humor that he occasionally displayed. The world of scholarship was the one he chose for his own life, but he honored many other mental and physical pursuits. For those he loved and respected, he had a warm and generous heart.

Beverly Blair Cook

University of Wisconsin, Milwaukee

\section{Regis A. Factor}

Regis A. Factor, professor of government and international relations at the University of South Florida, St. Petersburg, died of ALS on April 18, 1999. He was born in Pennsylvania in 1937. He attended Washington and Jefferson College and then entered the Army, working in the Counter Intelligence Corps and perfecting his command of European languages. He entered the Johns Hopkins School of Advanced International Studies, where he received a masters in 1966. At this time, his interests shifted, partly in response to his SAIS experience, partly (perhaps) to his experiences on the Bologna campus and in Italy, where he worked and had an opportunity to immerse himself in the local culture. He developed a stronger interest in the normative, and especially a belief in Catholicism as a means of thinking normatively about politics.

He became a student of government, specializing in international relations theory at the University of Notre Dame. The pull of political theory gradually increased, and he wrote his dissertation on Hans $\mathbf{J}$. Morgenthau. In many ways, the dissertation provides an entre into the concerns of his later writing. In 1972 he was hired as the first political scientist in a startup program on the St. Petersburg campus of the University of South Florida. He served this campus and program faithfully for the rest of his career. He was an influential teacher who touched the lives of many students and encouraged the organizational efforts of students to create organizations that would provide a forum for serious and engaged thinking about public matters. He brought major scholars to this small campus and actively encouraged his students to be ambitious in both thought and political action. In St. Petersburg, Regis was an active Catholic layman. His profound personal engagement with the church, habits of study and reflection, and simple devotion, are in many ways inseparable from his intellectual life. His interests were wide and remarkable, ranging from the European sources of Vatican social teaching to a long-term fasci- nation with the films of Stanley Kubrick.

Although a sizeable portion of his published work was produced in the course of our own long-term collaboration on Weber, the trajectory of the work was distinctively his. Together, we produced two books, Max Weber and the Dispute over Reason and Value (Routledge, 1984) and Max Weber: The Lawyer as Social Thinker (Routledge, 1994), and more than a dozen articles and chapters (some of which we used in our books), as well as minor items of record such as an article on Weber for the Routledge Encyclopedia of Philosophy. In addition, Regis produced a study of the Archive fur Sozialwissenschaft und Sozialpolitik (perhaps the greatest journal in the history of the social sciences), which included a substantial scholarly essay and an extensive bibliographic tool for users of this journal, and a lengthy manuscript, which will be published posthumously.

We began working together as a result of a discussion of the structure of the critiques of positivist social science found in Habermas and Leo Strauss and our mutual recognition of the many logical similarities between the superficially dissimilar arguments. The whole series of complex philosophical issues involving the basic concepts of value, value choice, relativism, historicism, and so forth was obviously central, and we recognized immediately that there was a personal thread to many of these disputes that was largely unacknowledged by (but accessible to) the post-World War II writers on these issues.

This research opened a path into a concern that motivated Regis throughout his life and hovered behind most of his thinking: the moral problem of Nazism and the question of its intellectual sources, and the larger question of modernity, neither of which could be understood apart from the other. In actuality, of course, these motivating questions were sublimated into scholarship. I should note that ours was a collaboration of opposites, but an effective one. His intellectual Catholicism, which I did not share, lent an interesting and sometimes very complex 
flavor and dynamic to our work together, in which we never disagreed on substance, despite our very different starting points. We became concerned with the original context of Weber's own quite radical thinking on these topics and with the puzzle of his own sources and context, but also with the peculiar history of its reception, critique, and transformation. The reception history we treated in our first Weber book, the contextual study we detailed in our second. Studying context and, indeed, getting a feel for the salient problems of the time is incvitably a large part of both kinds of projects, and very little of the background reading actually appears in the text.

In working on this period, the period before World War I, Regis discovered the writings of a group of German Jesuits that provided an exposition and critique of the dominant legal and social and political theories of non-Catholic thinkers and also provided a critique of the modernity the theories represented. Regis, who admired great scholarship above all else, became fascinated with these largely lost figures. He began to work on a large work on their critique of modernity and of modern social and economic life. In a way, this project paralleled the Weber reception project in that $\mathrm{Re}$ gis became aware of the innumerable subterranean influences of these thinkers on later Catholic political thinking and especially on papal responses to modernity. But he emphasized what they said rather than its reception. This work will be edited by a friend and published posthumously, and it will be the best possible scholarly memorial. It was a project that employed both his linguistic and intellectual skills as well as deriving its impetus from his own strong intellectual affinity for these thinkers and the issues that these thinkers were concerned with.

Regis once described himself as "persevering, obdurate, and uncompromising." And this was true, as far as it went. In the domains over which he had some control, however, he was quite different. His links with the international community of Catholic scholars and some intense scholarly correspondences, together with a fundamental optimism and generosity toward others, cnabled him to live the life of a scholar rather than a "professional," and served as a reminder that the university could still mean what it meant for Newman. His classes were a model of Socratic dialogue, and he was loved by his students. His Aristotelean sense of virtuous action led him to seek out occasions for political action in which, to use a Weberian phrase, compromises with the devil were unnecessary. He found several, including the Catholic Right to Life Movement and an interesting effort to force universities to follow the wishes of donors. He found some opportunities for action with the university as well, including service on some crucial committees where his stalwart support of scholarly quality was needed. But for the most part, his university political role was restricted to helping students organize, at which he excelled. He rejected the usual compromises of academic life, and at a high price. In this respect he became like the figure from Weber that, I think, always haunted him: the conviction politician who understood politics and sought a political outlet but was denied it by circumstances and by his own moral standards.

Stephen P. Turner University of South Florida

\section{Arvid Pardo}

Arvid Pardo, diplomat, international civil servant, rigorous scholar, and university professor, passed away on June 19, 1999, in Seattle, Washington. He was born in Rome, Italy, on February 12, 1914.

He will be remembered on many accounts, perhaps principally for his innovative proposals relating to the development and reformulation of the international law of the sea. His concern for the equitable sharing of the benefits derivable from the exploitation of mineral resources, including polymetallic nodules, found on and under the deep sea bed and ocean floor (referred to the 1982 Law of the Sea Convention as "the area") led to the provision in Article 136 of that agreement that "The
Area and its resources are the common heritage of mankind."

The acceptance of this key provision of the 1982 treaty followed Ambassador Pardo's continuing and dedicated effort to obtain an overwhelmingly favorable vote for U.N. General Assembly Resolution 2749 (XXV) on December 17, 1970. As the Maltese representative during the early law of the sea negotiations, where he was able to enlist the support of developing countries, as well as to still many of the concerns of the advanced maritime states, he was able to obtain support for the principle, set forth in the General Assembly's Resolution, that "the sea-bed and ocean floor (hereinafter referred to as the area), as well as the resources of the area, are the common heritage of mankind."

Arvid Pardo attended the Collegio Mondragone, Frascati. His graduate studies led to a diploma in diplomatic history from the University of Tours, France, in 1938, and to a doctorate in international law from the University of Rome in 1939). This sense of independence and profound distrust of totalitarian regimes led him to become a member of the underground movement. He was discovered and was imprisoned in Italy and later in Germany between 1940 and 1945. His prison experience produced a life-long concern for the problems of the incarcerated.

With the formation of the United Nations, Dr. Pardo became a member of the early Secretariat, headquartered at Lake Success, New York. His service with the Trustecship Department began in 1945 , where he was a social atfairs officer and later an area officer. From 1945 to 1954 he was the deputy resident representative of the United Nations in Somalia, and from 1963 to 1964 in Ecuador.

When Malta obtained membership in the UN, Dr. Pardo was appointed in 1964 as its permanent representative, which office he held until a change of government in Malta in 1971. The government of Malta appointed Dr. Pardo as its ambassador to the United States and the Soviet Union (1967-71) and as the Maltese High Commissioner to Canada (1969-71). 